\title{
Vandbehandling \\ - fra regnvand til drikkevand
}

\section{J, C, Blandfort og Knud Pedersen, DGE Group}

Da Harald Blåtand (911-987) arvede tronen efter sin fader Gorm den Gamle og samlede og kristnede danerne, havde man også regnvejr i Danmark. En del af regnen sivede ned $i$ undergrunden og dannede grundvand, som man i nutiden indvinder i 85 meters dybde ved Rugballegård uden for Horsens by og renser ved traditionel dansk vandværksbehandling for at levere det som drikkevand til Horsens bys indbyggere. Der er således tale om uforurenet grundvand.

Ca. 900 år efter at Harald Blåtand begyndte den industrielle udvikling i Danmark, hvor blandt andet den kemiske industri begyndte at dukke op i Danmark og gennem det sidste århundrede, har vi mennesker udnyttet kemi $i$ vor higen efter bedre og lettere livsbetingelser. Vi troede, at vi kunne besejre naturen blandt andet med kemiske produkter, så vi glemte at leve i takt med naturen. Vi troede, at naturen kunne kapere og rense alle vore kunstigt fremkaldte produkter, som vi benyttede os af og spildte somme tider i stor mængde, bare vi fik det lettere og ikke blev slidt op i samme unge alder, som vore forfædre blev det.

\section{Vi er blevet klogere}

I det sidste halve århundrede er vi imidlertid blevet ret så meget klogere. Vi har således lært, at naturen ikke kan kapere og rense op efter vore forsømmelser med forurening med de industrielt frembragte kemikalier. Mange steder i Danmark som fx på øen Endelave indvinder man grundvand, som er dannet gennem de seneste årtier, hvorfor det kan være belastet med afsmitning af de menneskelige aktiviteter, som vi netop nu foretager os.

Der er en politisk beslutning i Danmark om kun at udnytte uforurenet grundvand til fremstilling af drikkevand. I nærværende artikel skal der redegøres for de tiltag, som skal iværksættes, når vi producerer godt drikkevand på grundvandsværker, der er bygget efter dansk tradition, hvor vi tilsigter

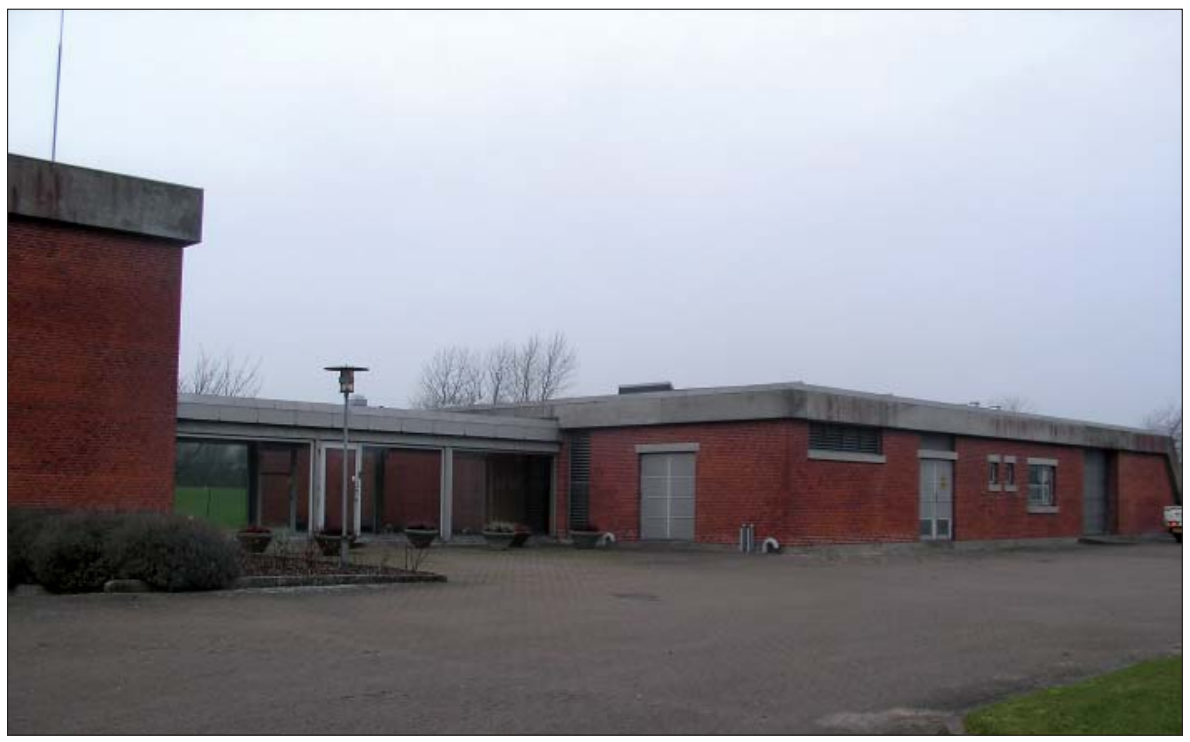

Rugballegårdvcrket (1976) i Horsens er placeret i et industriområde, hvorfor vandbehandlingen sker i et lukket kredsløb, hvor der benyttes ren oxygen til iltning af vandet. Herefter dobbeltfiltreres det iltede vand på høje lukkede filtre. Vandvcerket behandler grundvand, der er henholdsvis ca. 1.000 og 1.200 år gammelt fra to forskellige grundvandsmagasiner. (Foto: Ulla $V$. Hjuler)

at bruge naturens egne processer uden tilsætning af kunstige kemikalier.

\section{Bestemmelse af grundvandets alder} I gennem de senere år har der været snakket meget om grundvandsmagasinernes sårbarhed, og om hvordan grundvandet kan beskyttes mod forurening. Hvis man derfor vidste, hvor lang tid vandet har været undervejs, fra det faldt som regn, og til det pumpes op fra boringerne, så ved man med sikkerhed, om det kan have været udsat for moderne tiders forurening.

DGE har for en række vandværker forestået en aldersdatering af grundvandet, som er udført ved kulstof-14-datering på AMS 14C Dating Centre, Aarhus Universitet. Formålet med disse aldersdateringer har været formodninger i enkelte tilfælde om en forureningstrussel og $i$ andre tilfælde på grund af, at den kommunale planlægning af nye industriområder ikke tog hensyn til beliggenheden af eksisterende vandværkers boringer. I et enkelt tilfælde er dateringen

\begin{tabular}{|l|c|c|c|}
\hline Lokalitet & $\begin{array}{c}\text { Dybde på placering af } \\
\text { boringsfilter }(\mathrm{m})\end{array}$ & $\begin{array}{c}{ }^{14} \mathrm{C} \text {-alder } \\
\text { År }\end{array}$ & Kommentarer \\
\hline Endelave & Ca. $25-30$ & $<50$ & \\
\hline Give & Ca. 75 & Ca. 400 & $\begin{array}{c}\text { Der kan være } \\
\text { sammenblanding af } \\
\text { ældre og yngre vand }\end{array}$ \\
\hline $\begin{array}{l}\text { Bjerrbro ved } \\
\text { Brædstrup }\end{array}$ & Ca. $70-90$ & $750-800$ & \\
\hline $\begin{array}{l}\text { Rugballegård } \\
\text { ved Horsens }\end{array}$ & $85-110$ & $1.000-1.600$ & $\begin{array}{c}\text { Der er tale om to } \\
\text { adskilte magasiner }\end{array}$ \\
\hline $\begin{array}{l}\text { Højballegård } \\
\text { ved Horsens }\end{array}$ & $115-170$ & $1.250-2.800$ & $\begin{array}{c}\text { Der er tale om mindst } \\
\text { to adskilte magasiner }\end{array}$ \\
\hline Brande & 115 & Ca. 1.800 & \\
\hline Brædstrup Vandværk & Ca. 100 & Ca. 2.500 & \\
\hline Holsted & Ca. 180 & Ca. 3.000 & \\
\hline
\end{tabular}




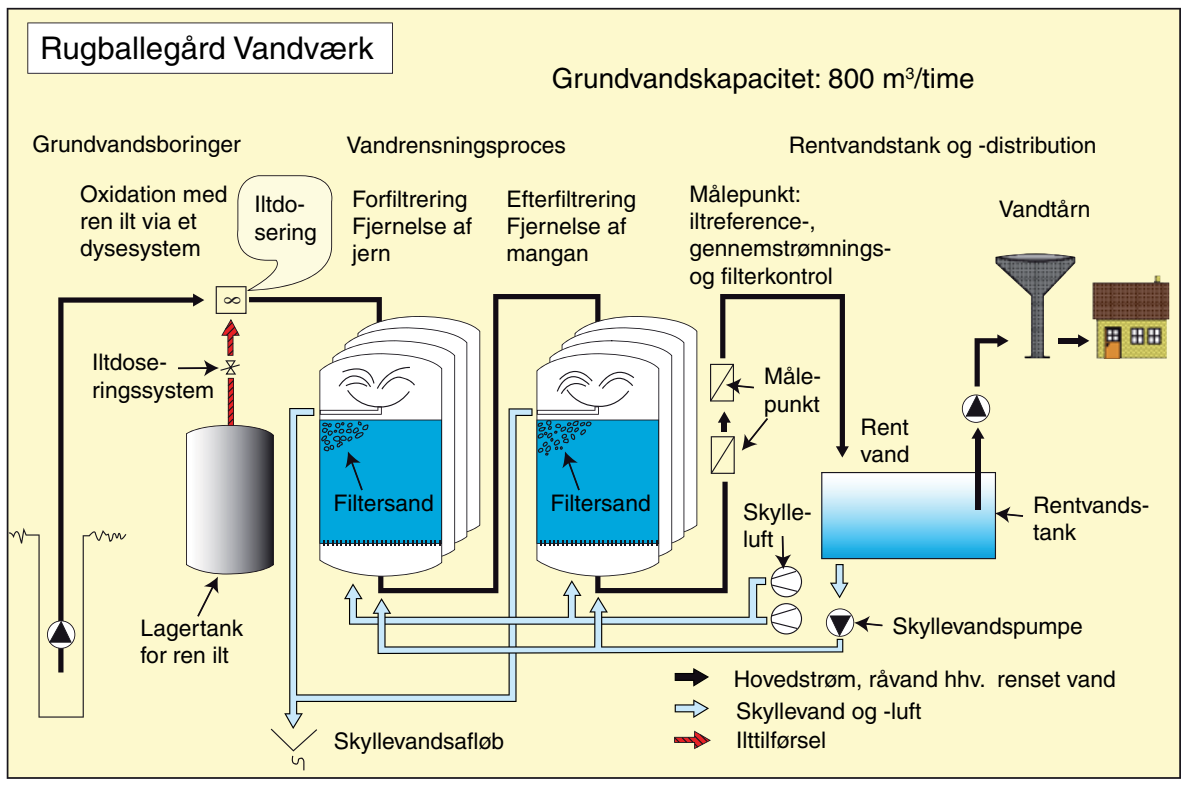

Principskitse over Rugballegård Vandverk. (Grafik: UVH modificeret efter folder fra vœerket)

brugt til en vurdering af vandets kvalitetsmæssige stabilitet over længere tid. Resultaterne er vist $i$ tabellen på foregående side.

Når man finder grundvand, der er et par tusinde år gammelt, som $\mathrm{fx}$ ved Brædstrup Vandværk, kan man være sikker på, at det på nuværende tidspunkt er godt beskyttet mod forurening. Dette betyder imidlertid ikke, at man bare kan forurene løs i dette område.

Det fortæller nemlig også, at om et par tusinde år vil menneskene, som lever til den tid, forbande os som værende nogle svin, der ødelagde naturen og deres drikkevand, hvis den overfladenære forurening ikke stoppes i vor livstid. Man skal tænke på de næste 100 til 200 generationer, som jo også gerne skulle bo i Danmark.

\section{Naturligt uforurenet grundvand?}

Grundvandet er som nævnt dannet af nedsivende regnvand - næsten destilleret vand normalt med et $\mathrm{CO}_{2}$-indhold, som først passerer igennem naturens vækstlag, hvor det bliver påvirket af muldjordens processer. Det kan ses fx på vandkvaliteten $\mathrm{i}$ indholdet af metan, ammonium og højt indhold af $\mathrm{CO}_{2}$, som er bestemmende for vandets pH-værdi. Herefter siver vandet dybere og reagerer med jordlagenes indhold af $\mathrm{CaCO}_{3}$, som bibringer vandet temporær hårdhed i form af opløste calcium- og hydrogenkarbonat-ioner. Hvis det nedsivende vand indeholder ilt eller nitrat, vil der kunne ske en iltning af pyrit $\left(\mathrm{FeS}_{2}\right)$, som giver vandet et indhold af jern og sulfat. Omvendt vil et indhold af bakteriologisk omsætteligt orga- nisk stof kunne forbruge sulfatens iltindhold under dannelse af svovlbrinte, der igen danner pyrit med jern. Der er således mulighed for en lang række processer, som langsomt vil kunne foregå og give vandet et indhold af opløste salte.

Den geokemiske afsmitning fra de forskellige jordlag giver mange mulige sammensætninger af grundvandet rundt om i Danmark. Vi er fortrolige med disse sammensætninger og med, hvordan vi skal rense det for svovlbrinte, metan, jern, ammonium og mangan samt neutralisere aggressiv $\mathrm{CO}_{2}$, hvor en mere end 100-årig tradition efterhånden har udmøntet sig i en dansk teknologi for grundvandsrensning, dog således at hver leverandør har sit eget design.

Den geokemiske afsmitning betyder imidlertid også, at der i grundvandet kan forekomme om end meget små mængder af stoffer, som man i dag tillægger en sundhedsrisiko. Ud fra gældende regler, som forudsætter, at man kan drikke vandet gennem sit hele liv uden at tage sundhedsmæssigt skade heraf, ser man i dag problemer i visse områder med indholdet af arsen. I andre områder er nikkel et problem på grund af pyrit-oxidation i grundvandsmagasinet. Endelig skal nævnes fluorid, som er et problem, der skal tages ret så alvorligt.

Uforurenet grundvand kendetegnes ved, at man i dag med alle vore fine målemetoder ikke kan påvise alle de syntetiske kemikalier, som mennesket har frembragt. Endvidere kræves der også, at grundvandet ikke er blevet påvirket ved menneskeskabte aktiviteter ved udnyttelse af naturens rigdomme $\mathrm{fx}$ tidligere tiders brunkulsgravning.

Uforurenet grundvand kan imidlertid godt indeholde stoffer, som man har svært ved at forstå, at naturen selv frembringer. For mere end 10 år siden påviste hollandske

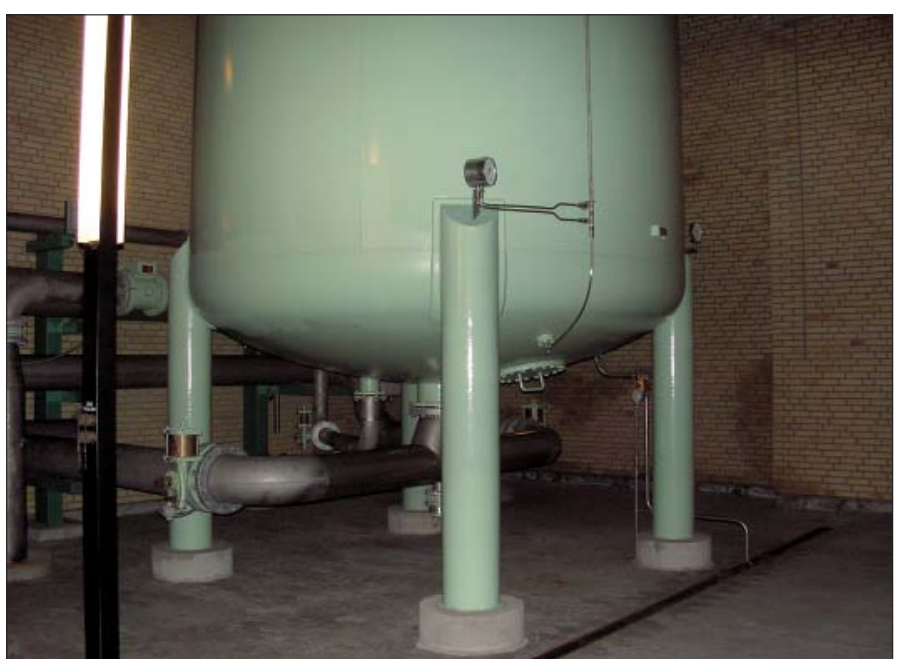

Lukket efterfilter på Rugballegårdvœrket. (Foto: UVH)

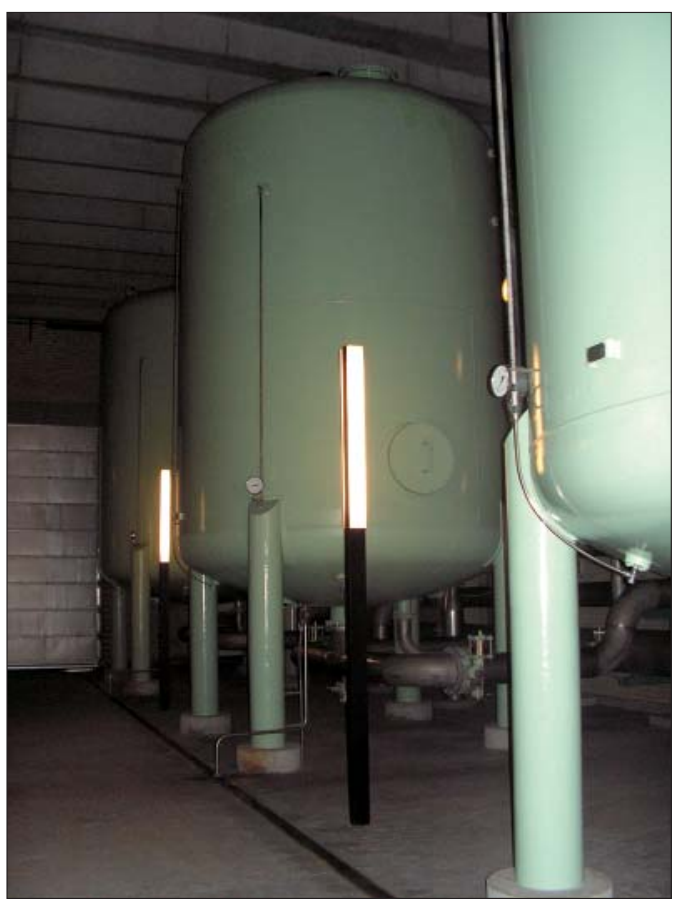

Lukkede forfiltre på Rugballegårdvœrket. Filtrene har et filterareal på $10 \mathrm{~m}^{2}$, et filtrerende lag på 2,8 m, og det drives med $150 \mathrm{~m}^{3} /$ time på hver af de 4 filtre. (Foto: UVH) 

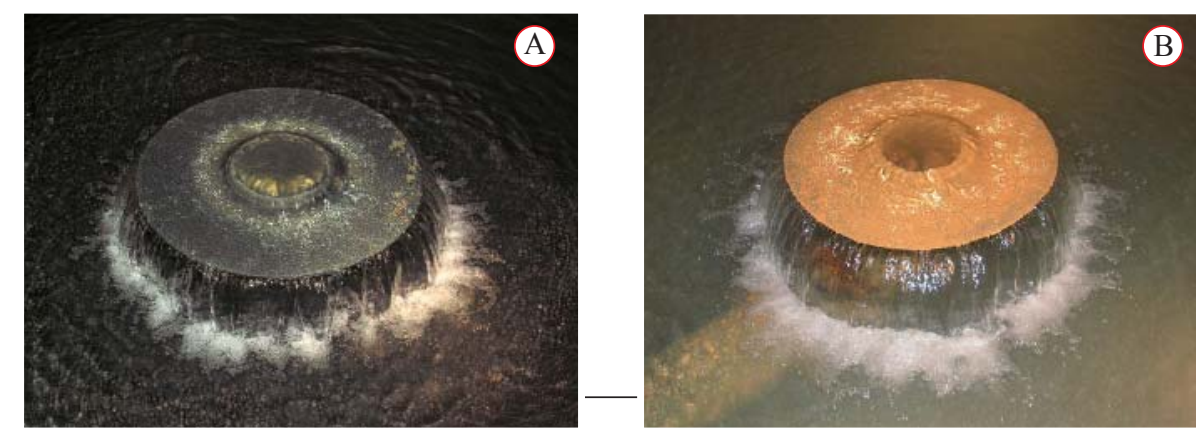

A) Efterfilter på Højballegårdvœrket. I filtret fjernes mangan ved en kombineret proces af ion-bytning og iltning med manganbakterier. Processen sker i de sorte belcegninger af manganoxider.

B) Åbne forfiltre på Højballegårdvœrket. I filtrene fjernes grundvandets jernindhold $i$ en kemisk katalytisk proces.

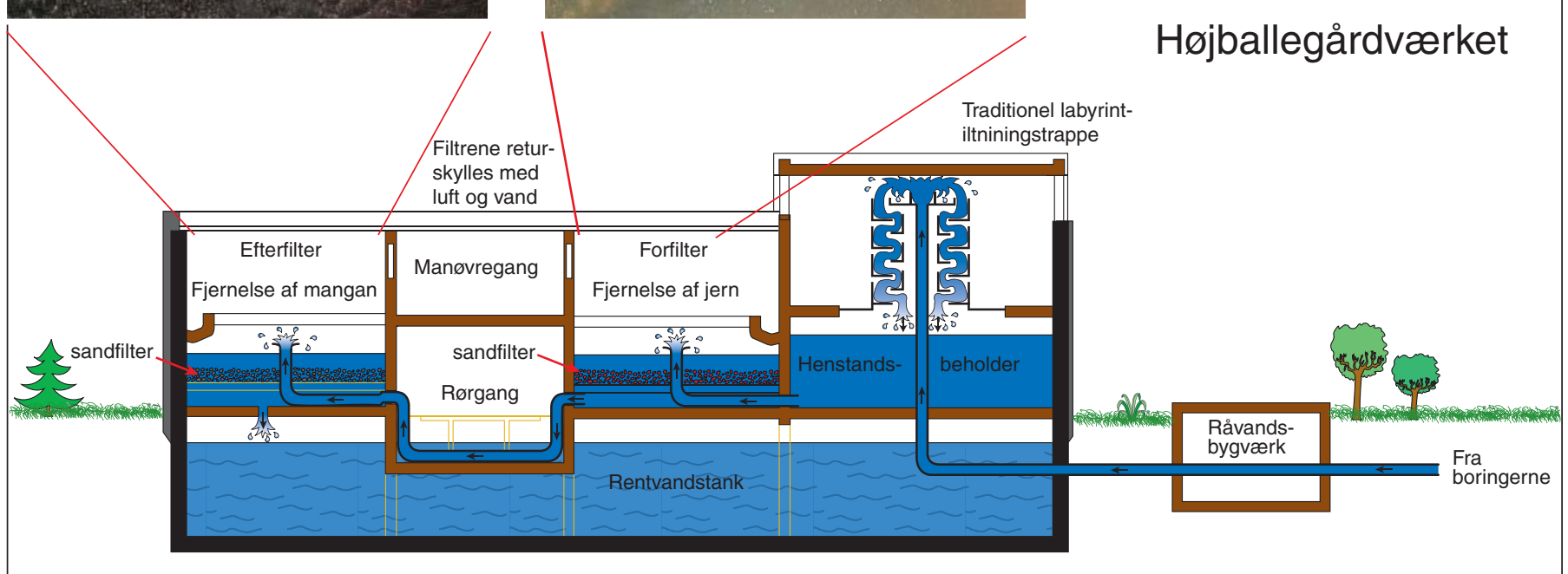

Snittegning af Højballegårdvcerket. (Grafik: UVH modificeret efter tegning fra Højballegårdvcerket)

forskere, at i kloridholdige aflejringer ville der kunne ske en naturlig bakteriologisk omsætning af organisk stof, der som et biprodukt producerede kloroform $\left(\mathrm{CHCl}_{3}\right)$, og sjovt nok kan det påvises i grundvand under fyrreplantager - selv i stor dybde.

Den danske tradition for behandling Den danske vandværksteknologi er udviklet til, gennem naturens egne processer uden

\section{Typisk vandvcerk}

Et dansk vandværk består normalt at en iltningsinstallation, som i enkelte tilfælde er udformet til også at afblæse uønskede gasser såsom svovlbrinte og metan. Fra denne installation ledes vandet til sandfiltre og gennemgår en enkelt eller dobbelt filtrering alt efter grundvandets beskaffenhed. Og så sørger naturen for gennem bakteriologiske og kemiske processer, at vandet bliver drikkeligt uden risiko for vort helbred.

Hvis der er aggressiv $\mathrm{CO}_{2} \mathrm{i}$ vandet, neutraliseres dette som oftest med kalk $\left(\mathrm{Ca}(\mathrm{OH})_{2}\right)$ eller med produkter af brændt dolomitkalk $\left(\mathrm{CaCO}_{3}, \mathrm{Mg}(\mathrm{OH})_{2}\right)$

De få steder, der er humus i grundvandet, koaguleres dette med aluminium eller jern for at opnå mulighed for at frafiltrere humus. tilsætning af kemikalier, at producere godt drikkevand ud fra grundvand.

Igennem tidernes Danmark har hver vandværksleverandør udviklet sit eget vandværksdesign, hvorfor landets utallige vandværker i det ydre ikke nødvendigvis ligner hverandre, men indendørs er princippet det samme. Filtreringsprocessen sker i henholdsvis åbne filtre eller lukkede filtre gennem tiderne udført i mange forskellige typer og designs, som alle bygger på mesterlære, hvor generation efter generation forsøger at forbedre værket.

Det er først i det seneste årti, at man videnskabeligt er begyndt at forske i vandværkets processer for at få en bedre forståelse af, hvad der sker i selve vandværksfiltret. I en tidligere artikel i dette blad (4/07) er beskrevet alle observerede muligheder for jernudfældninger, og dette forskes der bl.a.

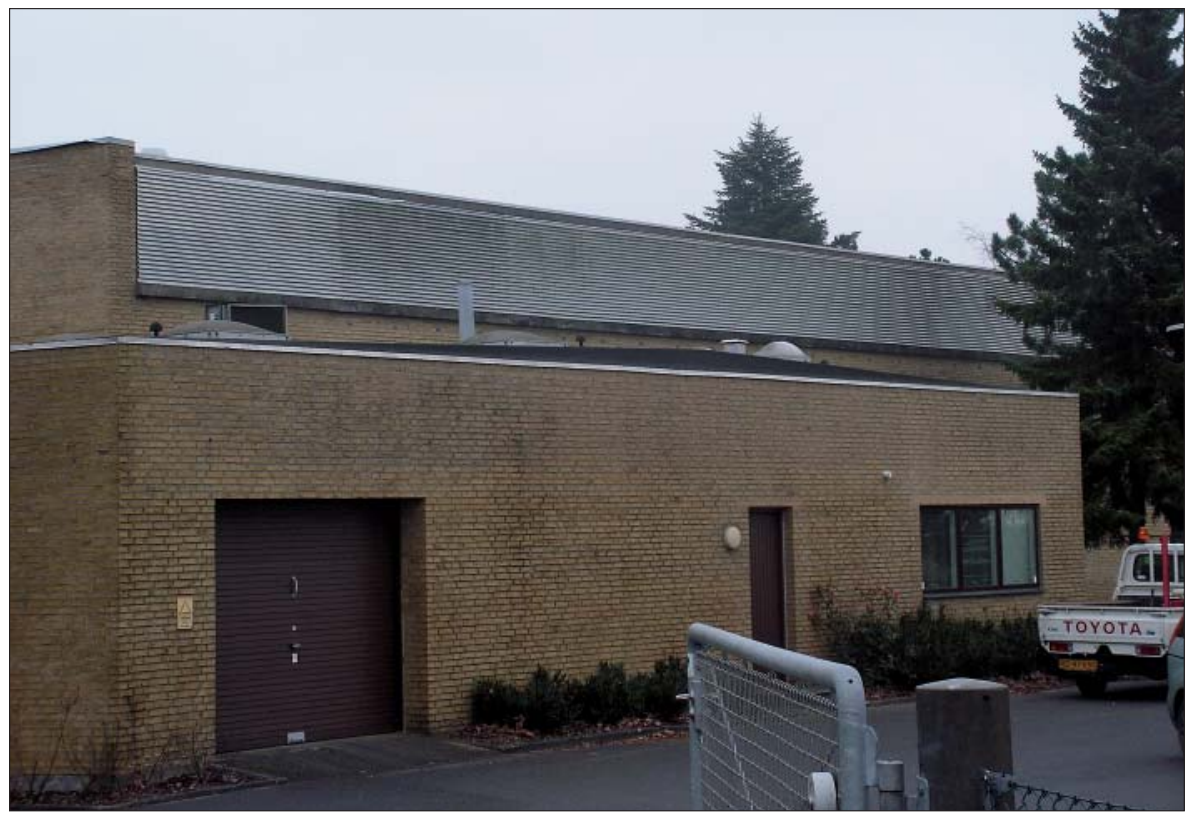

Højballegårdvœerket (1970) i Horsens er bygget i traditionel stil med iltningstrappe og dobbeltfiltrering på åbne filtre. Vandvcerket behandler 1.000 - 2.000 år gammelt grundvand og er det største vandvcerk uden for Københavnsområdet. (Foto: UVH) 
videre $\mathrm{i}$ for at forstå, hvorfor man af og til konstaterer, at filtermassen er sammenlignelig med en bakteriologisk zoologisk have bl.a. forårsaget af bakterieslim fra jernbakterier.

Siden 2003 har der været skærpede krav til indhold af ammonium $\left(\mathrm{NH}_{4}^{+}\right)$i drikkevandet, idet det fremover skal omsættes til nitrat $\left(\mathrm{NO}_{3}^{-}\right)$for at undgå nitrit $\left(\mathrm{NO}_{2}^{-}\right) \mathrm{i}$ vandet. Der er tale om en naturlig bakteriologisk proces, der sagtens kan foregå i et vandværksfilter, såfremt der er plads nok, og de rette livsbetingelser for bakterierne er til stede. Det volder problemer at overholde det skærpede krav på en række vandværker, idet disse er bygget før kravet kom, men ofte lykkes det alligevel at nå målet ved omlægning af driften.

\section{Mangelfuld omsætning af $\mathrm{NH}_{4}^{+}$til $\mathrm{NO}_{3}$} I det følgende vil vi prøve at forklare vandværksprocesserne på en utraditionel måde, som måske kan bedre forståelsen for, hvorfor der kan være problemer med den bakteriologiske omsætning af ammonium til nitrat.

\section{Grundvand}

Grundvandets bestanddele, som vi har mulighed for at gøre noget ved under den traditionelle danske vandbehandling, er
1. Svovlbrinte
2. Metan
3. Jern
4. (organiske bakteriebelægninger - bivirk- ning i mange filtre)
5. Ammonium
6. Mangan

Der er tale om en prioriteret rækkefølge, som ikke kan ændres. Der er endvidere tale om redoxprocesser, hvor:

$$
\text { reduceret stof } \rightarrow \text { iltet stof }+ \text { elektroner }
$$

Hvilket i vandværkets processprog betyder for vort drikkevand, at alle stabile stoffer skal være "fattige på elektroner" svarende til, at stofferne er iltede igennem i det iltrige miljø. Elektronerne spises på en eller anden måde af vandets iltindhold:

$$
\text { ilt }+2 \text { elektroner } \rightarrow \text { ilt-ioner }\left(\mathrm{O}^{2-}\right)
$$

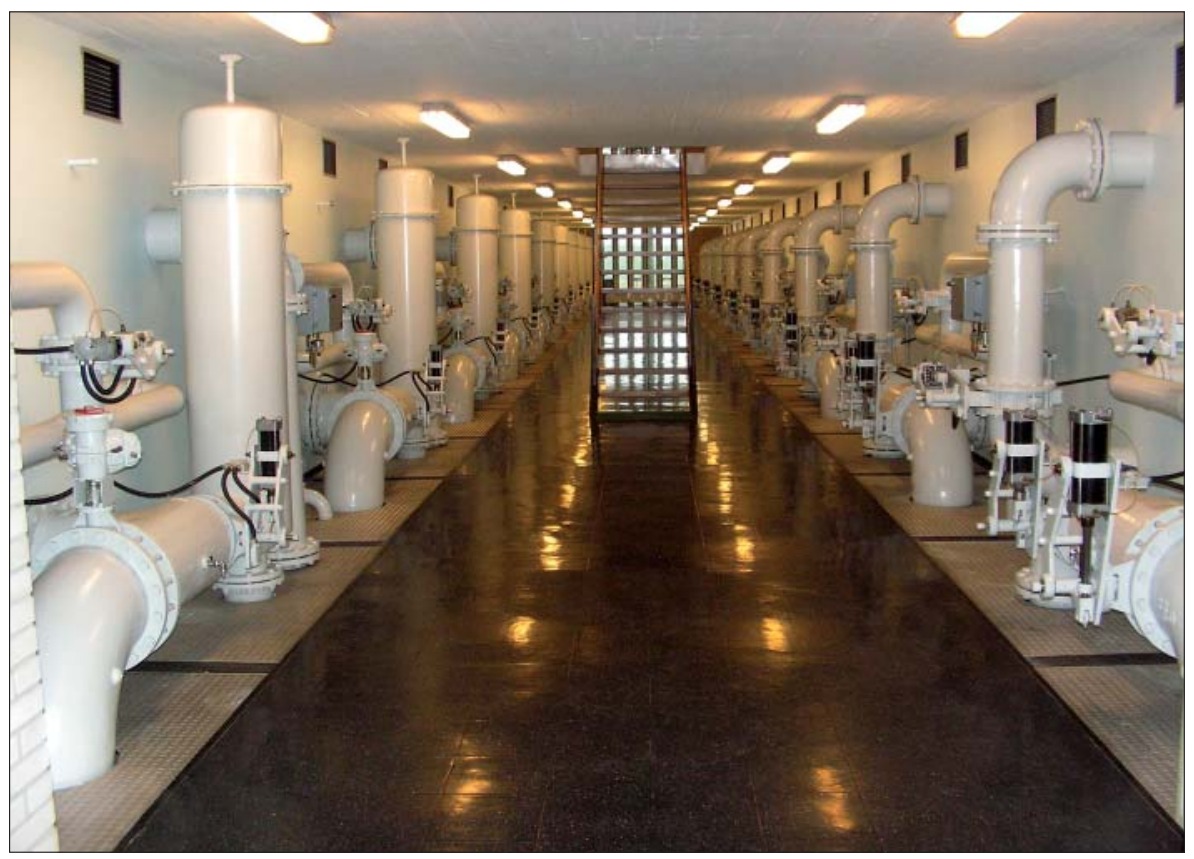

Filterfront på Højballegårdvcerket. Filtrene har en behandlingskapacitet på ca. $1.100 \mathrm{~m}^{3} /$ time. (Foto: UVH)

\section{Procesrækkefølge \\ 1. Svovlbrinte}

Der er tale om en prioriteret rækkefølge i behandlingsprocessen, hvilket reelt betyder, at når man ilter grundvandet, vil elektronerne lettest afgives af svovlbrinte, såfremt dette ikke afblæses $100 \%$ under beluftningen:

$$
\begin{aligned}
& \text { svovlbrinte } \rightarrow \text { sulfat }+6 \text { elektroner } \\
& 1,5 \text { iltmolekyler }+6 \text { elektroner } \rightarrow 3 \text { ilt- } \\
& \text { ioner }
\end{aligned}
$$

Processen er bakteriologisk, idet svovlbakterier transporterer og udnytter energien fra elektronerne, når disse omsættes med vandets iltmolekyler.

\section{Metan}

Herefter afgives elektronerne fra metan, såfremt det ej heller afblæses $100 \%$ under beluftningen:

methan $\rightarrow$ kuldioxid +8 elektroner

2 iltmolekyler +8 elektroner $\rightarrow 4$ ilt-ioner
Processen er bakteriologisk, da metanbakterier udnytter elektrontransporten. Metanbakterier er kendt for at danne bakterieslim (exopolymere sukkerforbindelser), som beskadiger filtermaterialet, og som fremmer bakterievækst i filtrene.

\section{Jern}

Med hensyn til elektronafgivelsen fra jern er der to muligheder, idet der vil være en kamp mellem biologisk afjerning (bakterier) og kemisk afjerning.

$$
\begin{aligned}
& \text { ferro-jern } \rightarrow \text { ferri-jern }+1 \text { elektron } \\
& 1 / 4 \text { iltmolekyle }+1 \text { elektron } \rightarrow 1 / 2 \text { ilt-ion }
\end{aligned}
$$

\section{Ryk tilbage til start}

Vandværksprocessen drejer sig i al i enkelthed om at flytte elektroner fra en række stoffer over til vandets iltmolekyler. Det lyder simpelt i teorien, men kan være forbandet svært i praksis. I gamle dages kemibøger lærte vi om Spændingsrækken - det er den, vi skal følge, og det er derfor, at reaktionerne forløber i en bestemt rækkefølge.

Problemet er imidlertid feltet, som er brugt i mange børnespil: RYK TILBAGE TIL START, thi det kan også forekomme i et vandværksfilter - og så går der "kagemand" i processerne. 

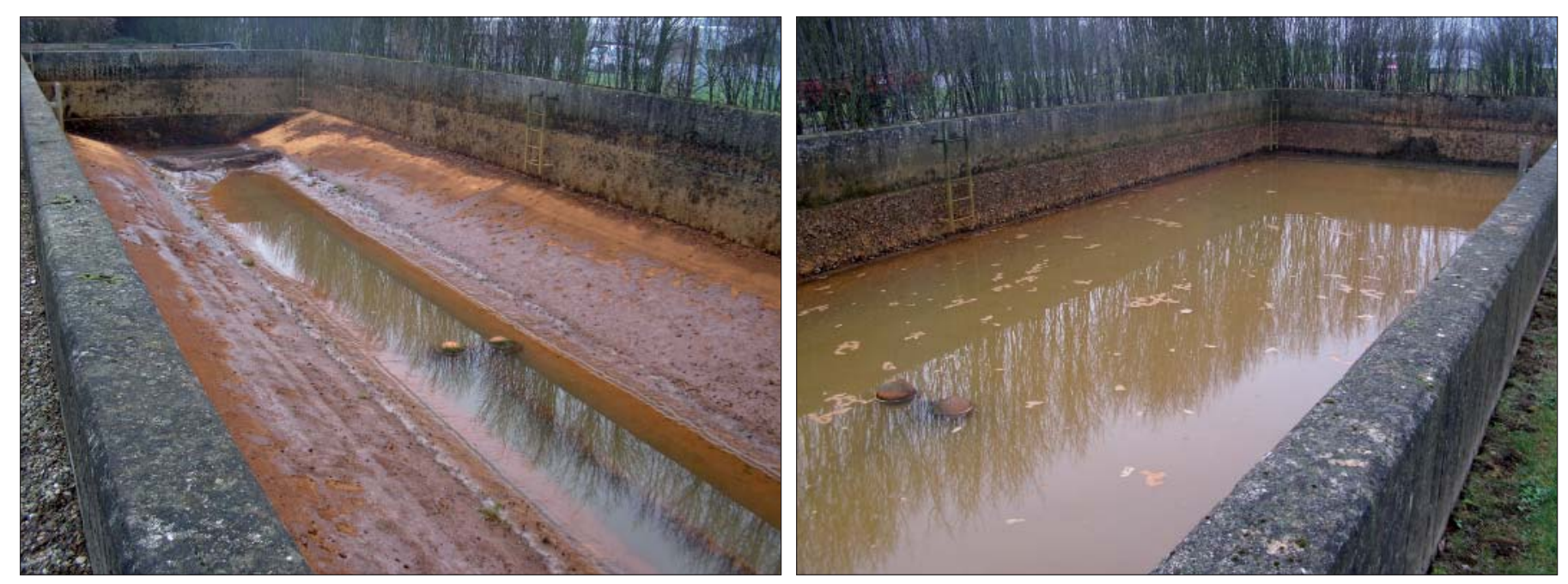

Skyllevandsbehandlingsanleg på Rugballegårdvœrket. I anlæegget bundfceldes jernslammet i skyllevandet, således at vandfasen kan udledes til den ncerliggende Torsted Bcek. (Fotos: UVH)

Vinderen af kampen mellem de to mulige afjerningsprocesser er den hurtigste proces, hvilket bestemmes af vandets $\mathrm{pH}$-værdi og redoxpotentiale. Ofte vil der være tale om en kombination af de to processer.

Den biologisk afjerningsproces danner bakterieslim (exopolymere sukkerforbindelser), som, vi har set forskellige steder, giver vækst af mikrobiologiske svampe og skimmel, der nedbryder stoffet i mindre bestanddele, der efterfølgende er "mad" for bakterier.

\section{Organiske belcegninger fra ovenncevnte processer}

Herefter kan så følge "the dark horse", idet der fra ovennævnte dannede organiske stof fra de biologiske processer skal omsættes:

$$
\text { organisk kulstof } \rightarrow \underset{\text { kuldioxid }+8 \text { elek- }}{\text { troner }}
$$

2 iltmolekyler +8 elektroner $\rightarrow 4$ iltioner

Det organiske stof sidder normalt som biofilm på filtermaterialet. Biofilmen har en tykkelse på få $\mu \mathrm{m}(1 / 1000 \mathrm{~mm}) \mathrm{og} \mathrm{er}$ normalt kendetegnet ved at være anaerob på indersiden. Dette betyder, at der absolut ingen iltmolekyler er til stede hér.

Iltforbruget til processerne hentes først og fremmest fra nitrat-ilt, og når dette er opbrugt så fra sulfat-ilt:

$$
\begin{aligned}
\text { nitrat } \rightarrow & \text { atmosfærisk kvælstof }+1 \frac{1}{2} \\
& \text { iltmolekyle } \\
\text { sulfat } \leftrightarrow & \text { svovlbrinte }+2 \text { iltmolekyler }
\end{aligned}
$$

Foregår disse processer i vandværkets filtre, vil den efterfølgende omdannelse af ammonium til nitrat og iltning af mangan blive mangelfuld - til tider være helt væk og måske først kunne ske i vandværkets rentvandstank.

Det er her vi har feltet "Ryk tilbage til start" - altså at rcekkefølgen af processer skal begynde forfra, hvis vi ikke passer på.

\section{Ammonium}

Herefter følger ammonium-omsætningen til nitrat. Der er tale om en bakteriologisk flertrinsproces:

$$
\begin{aligned}
& \text { ammonium } \rightarrow \text { nitrit } \leftrightarrow \text { nitrat }+10 \\
& \text { elektroner }
\end{aligned}
$$

$2 \frac{1}{2}$ iltmolekyle +10 elektroner $\rightarrow 5$ iltioner

Processen foregår som sagt ved hjælp af specielle bakterier, som gør brug af et kobberholdigt enzym til elektrontransporten.

Dette kobberholdige enzym forgiftes af svovlbrinte og sulfidsvovl.

Endvidere kan enzymets kobberatom kun fungere som transportør af elektroner, når vandets redoxpotentiale $\mathrm{er}>+90 \mathrm{mV}$. Det betyder, at alle andre "elektronprocesser", der kan foregå i et vandværksfilter ved lavere redoxpotentiale, skal være $100 \%$ tilendebragt, før end kobberatomet bliver tilgængeligt.

Da der er tale om en bakteriologisk proces, er der så også tale om, hvor meget ammonium der per time kan omsættes i et filtervolumen. De danske erfaringer udsiger her:

$8 \mathrm{~g}$ ammonium $/ \mathrm{m}^{3}$ filtermateriale/time 
Og det skal der være plads til i filterinstallationen, ellers bliver processen mangelfuld. Herefter vil manganfjernelsesprocessen også blive mangelfuld.

\section{Mangan}

Manganfjernelsesprocessen er en kombination af en kemisk ionbytningsproces og en bakteriologisk iltningsproces:

$$
\begin{aligned}
\text { mangano-Mn(II) } \rightarrow & \text { brunsten }-\mathrm{Mn}(\mathrm{IV}) \\
& +2 \text { elektroner }
\end{aligned}
$$

$1 / 2$ iltmolekyle +2 elektroner $\rightarrow 1$ ilt-ion

Bakterierne, der ilter mangan, gør brug af et kobberholdigt enzym, der forgiftes af svovlbrinte og et større indhold af nitrit.

Dette betyder, at mangelfuld omsætning af ammonium $\rightarrow$ nitrit $\rightarrow$ nitrat betyder ufuldstændig manganfjernelse.

Afhjælpning af mangelfuld omsætning Redoxpotentialemålinger gennem vandværkets procestrin kombineret med en

\section{Kort nyt}

\section{Lurende miljøkatastrofe i Østersøen} Under en orkan i Sortehavet 11. november brækkede en mindre russisk olietanker midt over ud for den ukrainske havneby Kertj. Tankskibet lækkede op imod 2.000 tons olie. Da tre andre fragtskibe, der transporterede svovl også sank i det voldsomme vejr med op til 6 meter høje bølger, blev der udløst katastrofealarm. 7.000 tons svovl menes at være strømmet ud i Sortehavet. De russiske myndigheder og miljøorganisationen Greenpeace betegnede udslippene som en miljøkatastrofe.

Med olie- og svovlforureningen i Sortehavet rettes søgelyset på ny mod Ruslands beregning af mulig plads for processerne vil normalt afdække, hvor problemet er.

Erfaringen giver følgende håndregler (krav til processerne):

1. Ved biologisk afjerning skal der være dobbeltfiltrering, således at ammoniumomsætningen kan foregå i efterfiltret.

2. Ved biologisk afjerning skal forfiltret skylles mindst hver anden dag.

3. Hvis der er mulighed for dannelse af bakterieslim i filtret, skal der skylles meget omhyggeligt og i lang tid med luft for at gnubbe biofilmen af filtermaterialet.

4. Periodevis bør der foretages to skylninger efter hinanden for at vurdere effekten af den normale skylning.

5. Der skal være effektiv ventilation i vandværkets beluftningsrum og filterrum, således at svovlbrinte i rumluften ikke forekommer, idet svovlbrinten genopløses i vandet - svarende til at rykke tilbage til start.

6. Der må ikke være mulighed for stagnationsvand ( $\mathrm{fx}$. i bunden af trykfiltre) noget steds i procesforløbet. Stagnationsvand kan

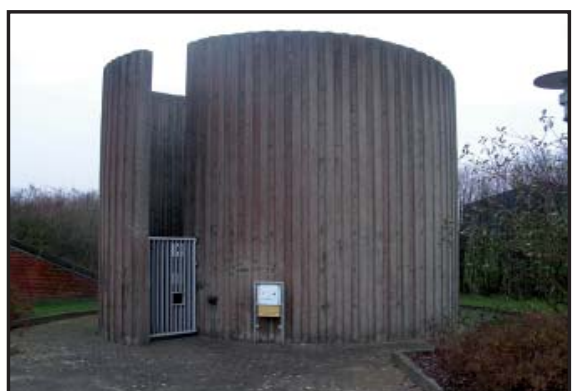

Tankanlceg for oxygen på Rugballegårdvcerket. (Foto: UVH)

resultere $i$, at vandets iltindhold bliver forbrugt, hvorefter ammonium passerer filtret uomsat.

7. Jernudfældningerne fylder for meget, så der ikke bliver plads til omsætning af ammonium. Det er et spørgsmål om at returskylle ofte nok.

Ovennæevnte erfaringer er med succes udnyttet til problemløsning på en rakke danske vandværker. eksplosivt voksende olietransport igennem de indre danske farvande. Tankskibstrafikken i Østersøen er nemlig de senere år vokset eksplosivt.

Ifølge Søværnets Operative Kommando er mængden af olie, der transporteres igennem de danske farvande siden 2002 , fordoblet. Det er sket i takt med, at væksten i den russiske olieeksport fra udskibningshavnen Primorsk, nordvest for Sankt Petersborg, er steget kraftigt.

I dag sender Rusland dagligt 1,5 mio. tdr. råolie fra Primorsk i Finskebugten ad den såkaldte rute $\mathrm{T}$ gennem Storebælt. Om få år, når olieudskibningshavnen i Primorsk er fuldt udbygget, vil Rusland årligt kunne udskibe 150 mio. tons råolie, som skal sejles gennem Østersøen, Storebælt, Kattegat og Skagerrak.

Selv om de fleste tankskibe, også de russiske, er dobbeltskrogede, så er der ingen garanti mod olieudslip i forbindelse med boringer, omlastninger på åben sø eller kæntringer i hårdt vejr.

De danske myndigheder står stort set magtesløse over for den stærkt stigende russiske olietrafik, og end ikke lodstvang kan gennemføres, fordi Storebælt er klassificeret som internationalt farvand. 